解 説

\title{
自動車産業における表面改質技術の応用
}

\author{
川名 淳 雄 ${ }^{\mathrm{a}}$ \\ a 日本コーティングセンター株)( ₹ 252-0002＼cjkstart神奈川県座間市小松原 1-43-34）
}

\section{Application of surface modification technology in the automotive industry}

\author{
Atsuo KAWANA ${ }^{a}$ \\ ${ }^{a}$ Japan Coating Center Co., Ltd. (1-43-34, Komatsubara, Zama-shi, Kanagawa 252-0002)
}

Keywords : PVD, EV, HEV, CrAIN, DLC

\section{1.はじめに}

自動車産業における表面改質技術，とりわけPVD 法によ るセラミックスコーティングは, 耐摩耗性あるいは摺動性を 生かし, 自動車部品の加工工具, 金型の耐久性向上に寄与し てきた。また, 環境問題を背景に $\mathrm{CO}_{2}$ ガスの排出削減を目 的とした燃費の向上に対し, 各種 PVD膜や DLC (ダイヤモ ンドライクカーボン)がエンジン駆動系の低摩擦化に貢献し ている。

一方, 自動車業界は, ここに来て大きな変革である, モー ターによる電動化に大きく舵を切った。IEA (International Energy Agency 国際エネルギー機関)の世界エネルギー展望の 予測では, 2020 年よりガソリン車は減少し, HEV (ハイブリッ ド), PHV (プラグインハイブリッド型)を含む EV 化へシフ トしてゆくものと思われ，2050 年にはガソリン車は $15 \%$ 程 度となる。この自動車の変化によって, 自動車を構成する材 料は大きく変化するものと思われる(図 1)。

ただ，EV化と言ってもエンジンがすべてモーターに置き
換わる訳ではなく, エンジンを動力とする自動車も 2050 年 でも $70 \%$ を占めると思われる。そのため, 今後も燃費向上 とともに自動車自体の軽量化が必要となる。本報告では, 軽 量化技術に関わる表面処理技術の応用について紹介する。

\section{2. 自動車部材の軽量化技術と表面処理}

自動車部材の軽量化は, 燃費の向上に寄与することから, これまで様々な取り組みがなされてきたが, 自動車の EV 化 に伴い, モーター性能や蓄電池の性能に対する寄与を考える と今後も軽量化に対する取り組みは継続すると思われる。こ れまでの自動車は, “鉄系材料”により作られてきたが，軽 量化のために軽合金材料, 樹脂材料, CFRP 材料などが検討 されており,これら材料の加工や成型のための表面処理への ニーズが高まってくると思われる。

また，これまでの自動車にはない電装品が使用され，モー ターを構成する部品, 各種制御機器に用いられる半導体製品 があり，これらの加工，製造に関わる表面処理技術も関わり が出てくると思われる。

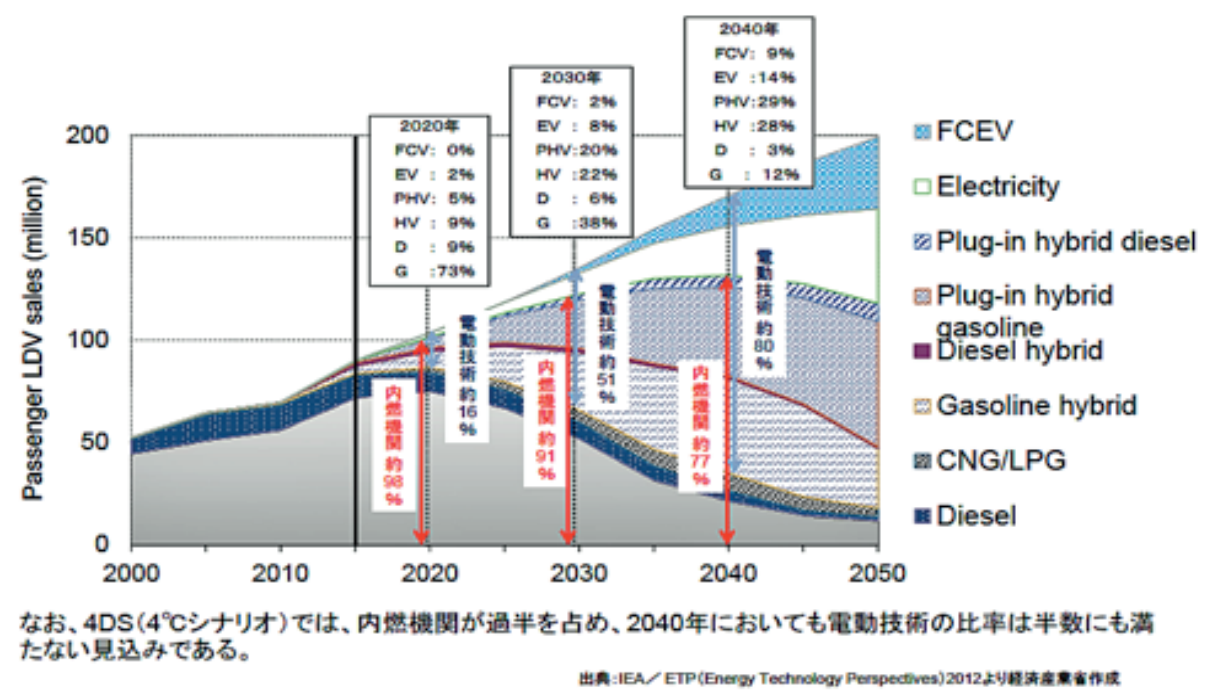

図 1 世界エネルギー展望 : IEA/ETP (Energy Technology Perspectives) 


\section{3． 軽量化材料と表面処理技術}

\section{1 鉄系材料}

軽量化とはいえ，安全性を考えると自動車の構造材料に鉄 系材料は欠かせない。車体を構成する鉄鋼材料のプレス成型 の金型に対し，各種表面処理が使われてきた。金型用表面処 理としては CVD 法や TD 法のように強固な付着力を持った 被膜が用いられてきたが, 高温处理による金型の変寸や金型 精度が保持できない等のデメリットにより，低温で処理でき るPVD 法によるセラミックスコーティングが注目され， $\mathrm{CrN}$ や CrAlN 等の $\mathrm{Cr}$ 系窒化物膜が用いられるようになった。

また, 加工面圧の高い条件では, 基材に窒化処理を施し強 度を付与する図 2 に示すような「複合処理」を適用した ${ }^{1)}$ 。

鉄系材料の軽量化を進める一方, 衝突安全性を確保するた めに，高張力鋼板を適用するようになったが，成型時の金型 への負荷が高くなり，表面処理の重要性が増している。

当社では上記 $\mathrm{CrAl}$ 系被膜の複合処理を適用してきたが, 引張強度が $980 \mathrm{MPa}$ 以上の超高張力鋼の加工に対し, CrAl 系被膜の改良を行い, $980 \mathrm{MPa}$ 材の冷間鍛造加工に耐えうる 被膜を開発した ${ }^{2)}$ 。

金型用被膜の評価は，実際の加工試験でないと判断できな いため，公設の試験センター所有のプレス機を用いてきた。 今回 $980 \mathrm{MPa}$ 高張力鋼板(厚み $1.2 \mathrm{mmt}$, めっき無し)を加工
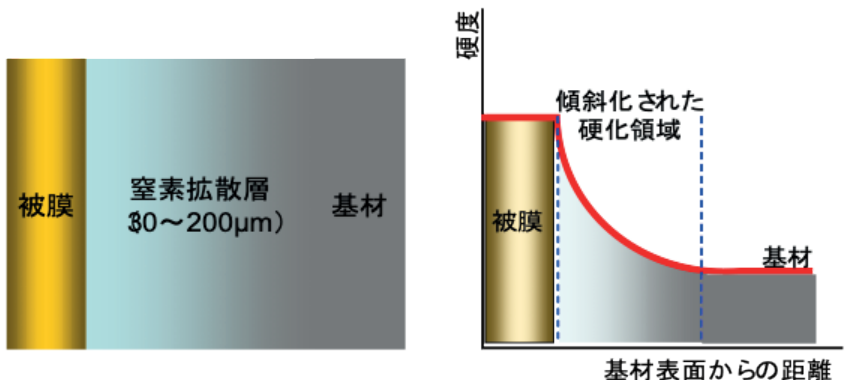

図 2 複合処理のモデル
するため, 大阪産業技術研究所所有のサーボプレス試験機 (H1F200/コマツ産機製)を用いた。プレス試験の模式図を 図 3 に, プレス試験後の中型と成形品の外観を図 4 に示す。 成形品の中央部にしわが寄り, 試験金型表面に高面圧がかか り，損傷を与える。

プレス試験での性能評価は, 未コート品, $3 \mu \mathrm{m}$ 程度の $\mathrm{CrAl}$ 系既存被膜，そして新たに開発した約 $10 \mu \mathrm{m}$ の $\mathrm{CrAl}$ 系 厚膜を評価した。コート品は 1500 ショット後の様子を観察 した。

その観察結果を図 5 に示す。未コート品は 50 ショット後 に観察しているが，それ以前から中型の損傷は大きかったと 推察される。またそれに伴い成形品の高面圧部は大きくつぶ れてしまっている。既存膜を適用した中型は 1500 ショット

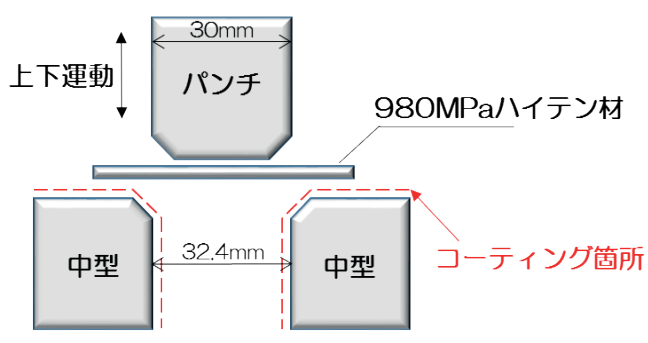

図 3 プレス試験模式図

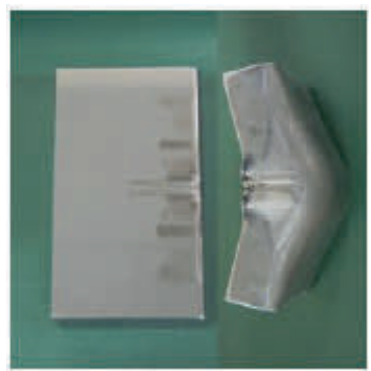

図 4 中型(左) と成型品(右)の外観

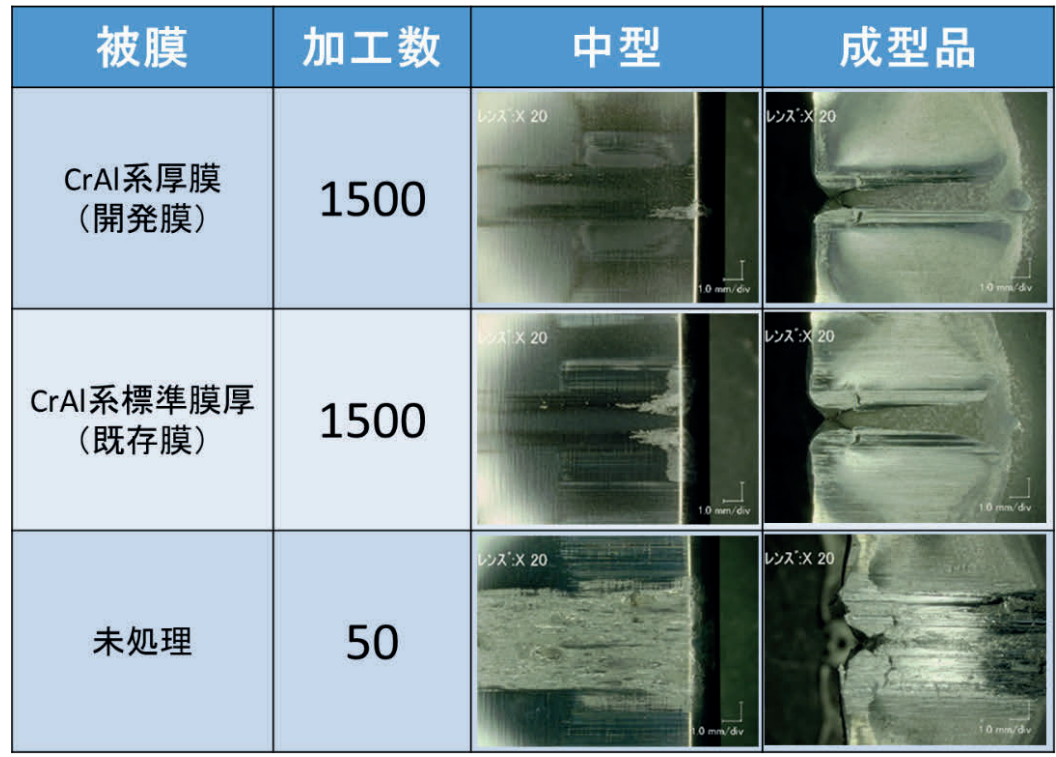

図 5 試験後の中型と成型品 
まで加工できたものの損傷は大きい。また成形品の高面圧部 におけるスクラッチ痕も多い。

それに対して開発膜の中型は 1500 ショット加工し一部損 傷はあるものの, 既存膜と比較して損傷程度は少なく, 成形 品も正常に加工できるという結果が得られた。

自動車メーカーではさらに高い引張強度, $1.2 \mathrm{GPa}, 1.5 \mathrm{GPa}$ 以上の高張力鋼板を使った加工開発を行っている。こうした 鋼材の加工ではホットスタンプ加工が用いられる。このため, 耐熱性の高い $\mathrm{CrAl}$ 系被膜が使用可能である。しかし，ホッ トスタンプ用鋼材は, スケール対策のため, 亜鉛やアルミめっ き鋼板が使われる。そのため, 金型表面の摩耗損傷よりもめっ きの亜鉛やアルミ残椬の付着が問題となるケースが多く，そ の防止のため, $\mathrm{CrAl}$ 系被膜表面に耐熱性 DLC 等の C 系の被 膜を被覆している。

\section{2 軽合金材料}

自動車用部材として用いられた軽合金材料は, アルミ合金 であろう。エンジン部のブロックやピストンなどに用いられ ている。今後 EV 化が進むとはいえ, 大半は HEV や PHV で ありエンジンは残る。また，課題であった鉄鋼材料との接合 技術の開発も進み，より一層のアルミ化が進むと思われる。

アルミ合金エンジンのシリンダーやピストンに対して, 潤 滑性を示すコーティングとして DLC 等が適用されている。 バルブリフターに水素フリーDLC が使われ，低フリクショ ンに寄与している。当社ではバルブピンには複合 DLC を適 用している。また, 水素フリーDLC は, アルミ切削用の工 具へ適用されている。

機械加工以外にアルミ合金自体の製造にも表面処理が使用 される。自動車シャーシを構成する $\mathrm{ADC} 12$ 等のアルミ合金 はダイカストにより鋳造される。アルミ溶湯中における耐溶 損性に優れた CrAIN 系被膜を開発し，アルミダイカスト用 ピンに適用している ${ }^{3)}$ 。ピン以外にもコマやチルベントにも 被覆し，寿命延長に寄与してきた。

アルミ合金以外にもマグネシウム合金などが部品として使 われようとしているが，その加工に対しても DLC や CrAl 系 被膜の効果が確認されている。

\section{3 樹脂系材料}

部品の樹脂化は比較的古くから行われており，フロントパ ネルやドアノブ，フェンダーといった構造部材以外へ適用が 進んでいる。また, FRP のモノコックボデイがレーシングカー から始まり，一般スポーツ車への採用が徐々に進んでいる。

さらに 2017 年 7 月の自動車保安基準の改訂で, ポリカー ボネート製のフロントウインドウが開発され，実車化された。 このウインドウ表面の耐摩耗性/耐候性コートはプラズマ CVD による硬質膜が適用されている。

樹脂材料の成型加工に対して PVD 処理は, 成型時の離型 性向上のために使われ, 現在でも TiN が射出成型機スク リューの表面処理に用いられている。上記のように樹脂の強 度を増すために添加された強化繊維によって耐摩耗性も求めら れるようになり， TiN の他に $\mathrm{CrN}$ 等 $\mathrm{Cr}$ 系被膜も使われている。

また，フロントウインドウに使用されるような高強度プラ スチックであるエンプラ材の耐摩耗性, 摺動特性の改善のた めの DLC コーティングを適用している。

\section{4 自動車産業構造改革で求められる材料}

100 年に一度と言われる自動車産業の大変革で, (1) Connected コネクテッド，(2) Autonomous オートノマス＝自動運転，(3) Shared シェアリング，（4）Electronic エレクトリック＝電動 化の 4 つの頭文字から「CASE（ケース）」と表現される新た なテクノロジーが求められると予想される。そのうち, 自動 運転, EV 化に伴い, これまで以上に車載電子部品が増加し, 各種センサー, 制御機器に対しては, 精密な機器に対し, 耐 熱性や耐衝撃性など過酷な環境での使用が要求され，新たな 半導体機器の開発が進むものと思われる。

当社でもこうした半導体製造分野への参入を見定め, 表面 処理施工のクリーンルーム化等の環境整備や高精密被膜開発 を進め, 半導体関連の応用開発を行った。

(1)極薄膜 DLC

半導体製造工程における $\mathrm{Si}$ ウエハをセットする治具や搬 送機器には, ナノメーターオーダーの膜厚均一性, ダストフ リーが求められる。このため, 治具にはプラズマ CVD 法に よる成膜により $\phi 300 \mathrm{~mm}$ の領域に $100 \mathrm{~nm} \pm 3 \mathrm{~nm}$ の DLCを ウエハホルダーに適用している。さらに添加元素により導電 性を付与したタイプの極薄膜 DLCもあり, 静電気対策もと られている。

(2)機能性被膜

半導体製造工程におけるエッチング工程では, 耐プラズマ エッチング性, ダストフリーが求められる。酸化物系被膜を 蒸着法で成膜している。また，封止モールドに関連した耐環 境性のガスバリア被膜の開発を進めている。

(3) ESD (Electro-Static Discharge) 対策用被膜

ESD による弊害, 静電気の急激な放電による半導体の損傷, 静電気によるダスト吸着, EMI (Electromagnetic Interference) 障害を軽減する被膜で，表面抵抗值 $10^{5} \sim 10^{11}(\Omega / \square)$ の領 域になるよう調整した DLCを適用している。

\section{4.おわりに}

自動車産業は，EV 化という 100 年に一度という大きな変 化点を迎え, 自動車を構成する材料が「鉄」から軽量材料に 転換が進んできた。PVD セラミックスコーティングは,「鉄」 を削る切削工具, 「鉄」を曲げる金型への表面処理として用 いられてきた。直ちにエンジンやトランスミッションが無く なるわけではないが，2030 年以降の自動車産業への寄与を 考えると，新なな応用技術を見い出す必要がある。

自動車は軽量化材料へ向かい, 加工技術の発展とともに表 面処理技術もその発展に寄与できればいいと考える。また自 動運転技術の発展には，電装系の制御技術とともに半導体関 連の製造にも関わる表面処理技術が確立できればより応用分 野が拡大するであろう。

(Received July 26, 2019）

\section{文献}

1 ）川名淳雄 ; 表面技術, 58, 440 (2007)

2 ) 稲垣真吾, 川名淳雄; 第137回講演大会要旨集, 13B-26 (表面技術 協会, 2018)

3 ) 斎藤邦夫; 型技術, 27, (2), 68 (2012). 